\title{
The Involvement of Genome Researchers in High School Science Education
}

\author{
Maureen Munn, ${ }^{1,6}$ Peggy O’Neill Skinner, ${ }^{2}$ Lane Conn, ${ }^{3}$ H. Geraldine Horsma, ${ }^{4}$ \\ and Paula Gregory ${ }^{5}$

\begin{abstract}
${ }^{1}$ Department of Molecular Biotechnology, University of Washington, Seattle, Washington 98195 USA; ${ }^{2}$ The Bush School, Seattle, Washington 98112 USA; ${ }^{3}$ Stanford DNA Sequencing and Technology Center, Stanford University, Palo Alto, California 94304 USA; ${ }^{4}$ Henry M. Gunn High School, Palo Alto, California 94306 USA; ${ }^{5}$ Human Cancer Genetics Division, Ohio State University, Columbus, Ohio 43210 USA
\end{abstract}

\begin{abstract}
The rapid accumulation of genetic information generated by the Human Genome Project and related research has heightened public awareness of genetics issues. Education in genome science is needed at all levels in our society by specific audiences and the general public so that individuals can make well-informed decisions related to public policy and issues such as genetic testing. Many scientists have found that an effective vehicle for reaching a broad sector of society is through high school biology courses. From an educational perspective, genome science offers many ways to meet emerging science learning goals, which are influencing science teaching nationally. To effectively meet the goals of the science and education communities, genome education needs to include several major components-accurate and current information about genomics, hands-on experience with DNA techniques, education in ethical decision-making, and career counseling and preparation. To be most successful, we have found that genome education programs require the collaborative efforts of science teachers, genome researchers, ethicists, genetic counselors, and business partners. This report is intended as a guide for genome researchers with an interest in participating in pre-college education, providing rationale for their involvement and recommendations for ways they can contribute, and highlighting a few exemplary programs. World Wide Web addresses for all of the programs discussed in this report are given in Table 1 . We are developing a database of outreach programs offering genetics education (http://genetics-education.mbt. washington.edu/database) and request that readers submit an entry describing their programs. We invite researchers to contact us for more information about activities in their local area.
\end{abstract}

Genomics Education as a Way to Facilitate K-12 Science Education Reform

Although publicity about the Human Genome Project (HGP) and biotechnology has increased public awareness, it has also raised concerns about many aspects of genetic research. These include the prospect of cloning humans, the limitations of genetic testing, the ethical ramifications of studying complex human traits like intelligence and behavior, and the risks associated with recombinant organisms. Genome researchers can make a substantial contribution to public understanding of these issues by collaborating in the development of educational programs focused on genomics. (See Table 1 for World Wide Web addresses of the programs discussed in this report.)

Over the past decade, increasing the science literacy of this country's populace has been a major focus of scientists, educators, and policy makers. Under the direction of the National Research Council (NRC) and the American Association for the Advancement of Science (AAAS), scientists and science educators have collaborated to develop national science education learn-

${ }^{6}$ Corresponding author.

E-MAIL mmunn@u.washington.edu; FAX (206) 685-7344. ing goals for kindergarten through grade 12 (K-12). These efforts have resulted in several formative documents from the AAAS $(1989,1993)$ and the NRC (1996a). These recommendations emphasize conceptual understanding, learning through inquiry, and learning how to apply science and technology to solve problems at the local, national, and global levels. Many states and local school districts are currently in the process of developing or revising their own academic learning goals in science using these national recommendations. As will be discussed later in this report, genomics offers many avenues for meeting these emerging science education standards while engaging students in the excitement of new scientific discovery in this field.

A variety of public and private agencies fund education in genomics (listed in Table 2). The National Science Foundation (NSF) provides considerable funding for education in this area as part of its broader efforts to support science education reform throughout entire school systems. Through its Advanced Technology Education (ATE) program, the NSF supports high school/college/industry partnerships that focus on the preparation of technicians for research in biotechnol- 
Table 1. Outreach Programs and Corresponding URLs

\begin{tabular}{|c|c|c|}
\hline Outreach program & Sponsoring institute & URL (http://) \\
\hline Access Excellence & Genentech, Inc. & www.accessexcellence.org \\
\hline A Question of Genes & $\begin{array}{l}\text { NoelEye Documentaries for Chedd/Angier } \\
\text { Production Company and Oregon } \\
\text { Public Television }\end{array}$ & www.pbs.org/gene \\
\hline BABEC & six San Francisco Bay area partnerships & www.babec.org \\
\hline Berkeley Biotechnology Education, Inc. & & hometown.aol.com/MAR1BBEI \\
\hline Biological Sciences Curriculum Study & Independent & bscs.org/ \\
\hline Bradbury Science Museum & Los Alamos National Laboratory & www.lanl.gov/external/museum/ \\
\hline CityLab & Boston University School of Medicine & www.bumc.bu.edu/citylab \\
\hline $\begin{array}{l}\text { Council of Regional Networks for } \\
\text { Genetic Services (CORN) }\end{array}$ & & $\begin{array}{l}\text { www.cc.emory.edu/PEDIATRICS/corn/ } \\
\text { corn.htm }\end{array}$ \\
\hline Distinguished Speaker Series & $\begin{array}{l}\text { TIGR Science Education Foundation, the } \\
\text { National Research Council and the } \\
\text { Department of Energy }\end{array}$ & www.tigr.org/cet/index.html \\
\hline Diving into the Gene Pool & San Francisco Exploratorium & $\begin{array}{l}\text { www.exploratorium.edu/genepool/ } \\
\text { genepool_home.html }\end{array}$ \\
\hline The DNA Files & SoundVision Productions & www.dnafiles.org \\
\hline DNA Learning Center & Cold Spring Harbor Laboratory & vector.cshl.org \\
\hline Gene Connection & $\begin{array}{l}\text { San Mateo County Office of Education } \\
\text { and Canada College }\end{array}$ & $\begin{array}{l}\text { nisus.sfusd.k12.ca.us/programs/sf_base/ } \\
\text { smcoe.html }\end{array}$ \\
\hline High School Human Genome Program & University of Washington & hshgp.genome.washington.edu \\
\hline Holiday Lectures on Science & Howard Hughes Medical Institute & www.holidaylectures.org \\
\hline $\begin{array}{l}\text { Howard Hughes Program at } \\
\text { Washington State University }\end{array}$ & $\begin{array}{l}\text { Program in Biology, Washington State } \\
\text { University }\end{array}$ & www.sci.wsu.edu/bio/hhp/index.html \\
\hline Human Genome Education Program & Stanford Genome Center & www-shgc.stanford.edu/bioed/ \\
\hline $\begin{array}{l}\text { Human Genome Teacher Networking } \\
\text { Project }\end{array}$ & Kansas University Medical Center & www.kumc.edu/gec \\
\hline Immunex Science Education Manager & Immunex Corporation & www.immunex.com \\
\hline $\begin{array}{l}\text { Lawrence Berkeley National } \\
\text { Laboratory's Human Genome } \\
\text { Program }\end{array}$ & Lawrence Berkeley National Laboratory & www.Ibl.gov/Education/ELSI/SJSCP.html \\
\hline $\begin{array}{l}\text { Lawrence Livermore National } \\
\text { Laboratory Education Program }\end{array}$ & Lawrence Livermore National Laboratory & ep.Ilnl.gov \\
\hline $\begin{array}{l}\text { Los Alamos National Laboratory } \\
\text { Education Program }\end{array}$ & Los Alamos National Laboratory & www.lanl.gov/external/education \\
\hline The Natural History of Genes & $\begin{array}{l}\text { University of Utah School of Medicine } \\
\text { Eccles Institute of Human Genetics } \\
\text { Utah Museum of Natural History }\end{array}$ & raven.umnh.utah.edu \\
\hline North Carolina Biotechnology Center & State of North Carolina & www.ncbiotech.org \\
\hline $\begin{array}{l}\text { ORNL Office of University of and } \\
\text { Science Education }\end{array}$ & Oak Ridge National Laboratory & www.ornl.gov/seer/OUSE.html \\
\hline Outreach and Education Office & $\begin{array}{l}\text { National Human Genome Research } \\
\text { Institute }\end{array}$ & $\begin{array}{l}\text { www.nhgri.nih.gov/Policy_and_public_ } \\
\text { affairs/Education }\end{array}$ \\
\hline RISE & National Research Council & www.nas.edu/rise \\
\hline $\begin{array}{l}\text { Santa Clara County Biotechnology } \\
\text { Education Partnership (SCCBEP) }\end{array}$ & $\begin{array}{l}\text { Santa Clara County Office of Education } \\
\text { and San Jose State University }\end{array}$ & $\begin{array}{l}\text { www.milpitas.k12.ca.us/mhs_website/ } \\
\text { departments/science/sccbep.html }\end{array}$ \\
\hline Science Education Partnership & Fred Hutchinson Cancer Research Center & www.fhcrc.org/ sep \\
\hline $\begin{array}{l}\text { Science + Literacy for Health: Human } \\
\text { Genome Project }\end{array}$ & $\begin{array}{l}\text { AAAS Directorate for Education and } \\
\text { Human Resources Programs }\end{array}$ & ehrweb.aaas.org/ehr/books/index.html \\
\hline SF-BASE & San Francisco Unified School District & $\begin{array}{l}\text { nisus.sfusd.k12.ca.us/programs/sf_base/ } \\
\text { welcome.html }\end{array}$ \\
\hline UCSF SEP & $\begin{array}{c}\text { San Francisco Unified School District and } \\
\text { University of California San Francisco }\end{array}$ & www.ucsf.edu/sep \\
\hline
\end{tabular}


Table 2. Agencies that Fund Genome Education

\begin{tabular}{|c|c|c|}
\hline Agency & Description & URL (http://) \\
\hline Community of Science & $\begin{array}{l}\text { searchable database of government and private } \\
\text { funding opportunities }\end{array}$ & Fundingopps2.cos.com \\
\hline $\begin{array}{l}\text { DOE, Office of Energy } \\
\text { Research }\end{array}$ & $\begin{array}{l}\text { funds educational activities in the areas of ethical, } \\
\text { legal, and social implications of genome research }\end{array}$ & www.er.DOE.gov \\
\hline Durfee Foundation & $\begin{array}{l}\text { in partnership with Earthwatch; provides funding for } \\
\text { students to spend } 2 \text { weeks during the summer at a } \\
\text { scientific research station }\end{array}$ & www.durfee.org/index.html \\
\hline $\begin{array}{l}\text { Genentech Foundation for } \\
\text { Biomedical Sciences }\end{array}$ & $\begin{array}{l}\text { provides funds to San Francisco Bay Area schools for } \\
\text { science education at all levels, from grade school } \\
\text { through the postgraduate level }\end{array}$ & $\begin{array}{l}\text { www.gene.com/Company/Responsibility/ } \\
\text { index.html }\end{array}$ \\
\hline $\mathrm{HHMI}$ & $\begin{array}{l}\text { makes most awards through national competitions in } \\
\text { which selected institutions are invited to submit } \\
\text { proposals according to prescribed criteria }\end{array}$ & www.hhmi.org \\
\hline NIH, NHGRI & funds education activities through ELSI & www.nhgri.nih.gov/About_NHGRI/Der/Elsi \\
\hline NSF & $\begin{array}{l}\text { funds educational efforts, both formal and informal, } \\
\text { through their Education Program Area. Funding for } \\
\text { biotechnology training provided by the Advanced } \\
\text { Technology Education program }\end{array}$ & www.nsf.gov \\
\hline Partners in Science & $\begin{array}{l}\text { funds partnerships between research faculty at a } \\
\text { college or university and a high school science } \\
\text { teacher in the Pacific Northwest }\end{array}$ & $\begin{array}{l}\text { M.J. Murdock Charitable Trust } \\
\text { M.J. Murdock Executive Plaza, Suite } 710 \\
703 \text { Broadway } \\
\text { Vancouver, WA } 98660 \\
\text { (360) } 694-8415\end{array}$ \\
\hline
\end{tabular}

ogy. Both the Department of Energy (DOE) and the National Human Genome Research Institute (NHGRI) commit 3\%-5\% of funding for the HGP to the exploration of the ethical, legal, and social implications (ELSI) of its research, and basic education in genomics is funded through these ELSI programs. Industry and private organizations like the Howard Hughes Medical Institute (HHMI) are also major supporters.

We believe that the most effective avenue for educating large segments of the population in genetics, biotechnology, and genome science is through high school biology courses, and the best way to reach the students in these courses is through their teachers. National studies indicate that $>95 \%$ of all high school graduates take a course in biology, whereas only $51 \%$ study chemistry, and $22 \%$ study physics (statistics for 1994; Council of Chief State School Officers 1995). In our experience, high school students have the maturity, interest, and scientific background to understand the concepts of genomics and the related ELSI topics, making this an appropriate time to explore these issues. Biotechnology and genome science also offer students a wide variety of career opportunities that will continue to expand in coming years.

\section{Critical Components for Education in Genomics}

The field of genomics offers exciting options for meeting science learning goals because of its relevance and inherent appeal to students, potential to do hands-on experiments in classrooms, and career opportunities. In this section, we discuss four major areas that need to be addressed to provide quality education in genomics.

\section{Accurate Scientific Information}

To evaluate issues in genomics, students need to comprehend the organization of biological information from DNA to genes, gene expression, and the assembly of complex biological systems. They should also understand that both genetic and environmental factors contribute to complex human traits like intelligence, behavior, and multifactorial diseases like cancer and heart disease (McInerney 1995). Courses and programs should also convey the possibilities and limitations of current technologies, their applications in other fields, as well as resources for finding up-to-date, accurate information.

\section{Experience with Experimental Processes}

Many of the techniques that are fundamental to genome research and biotechnology, such as restriction analysis, the PCR, and DNA sequencing can be carried out in a high school classroom and have become integrated into a small number of classrooms nationwide. Conducting experiments in genetics and molecular biology solidifies students' understanding of these topics by integrating abstract concepts into a concrete experience. In some cases, as illustrated in Figure 1, students are able to carry out research projects in collaboration with scientists or their classroom teacher.

\section{Applying Scientific Knowledge in Making Decisions About Related Social and Ethical Issues}

The ELSI topics that arise as the human genome is sequenced demand that we educate the public in ways to address them. Several teaching methods have been de- 
A

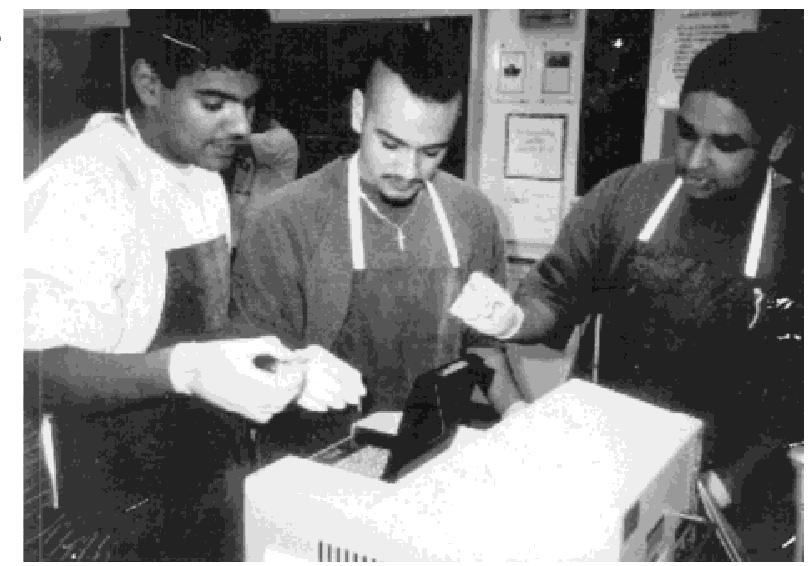

B

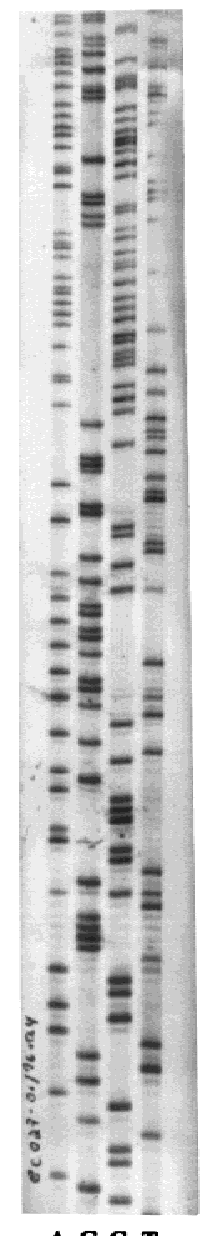

A C G T

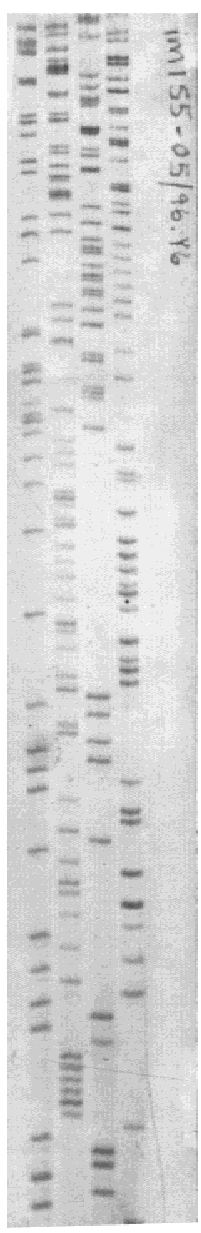

A C G T

Figure 1 High school students participate in authentic research projects. (A) Through a project developed at the Human Genome Education Program at Stanford University, local high school students participate in an experiment called DNA Snapshots-Peeking at your DNA. Students use PCR to amplify DNA from their own cheek cells and examine human relatedness through DNA similarities, in parallel to the process used to help locate lost children from the "Dirty War" in Argentina. Through this compelling human story, students learn DNA basics while exploring issues of privacy, family, and legal issues surrounding DNA typing and its uses. (B) The High School Human Genome Program enables teachers and students in the Seattle area to sequence human DNA in their classrooms. In the sequencing ladders shown here, students analyzed short segments of DNA from human chromosome 5, in collaboration with the laboratory of Mary-Claire King (Lynch et al. 1997). Students also explore some of the ethical issues of DNA technology
testing for Huntington's disease.

veloped to help students apply their understanding of genetics and other knowledge to real world problems. These decision-making models provide a framework for tackling complex ELSI topics by asking students to identify the ethical issues, relevant facts, stakeholders and principles, discuss possible options, and then select and justify the best option (Mertens and Hendrix 1982; Brinckerhoff and Zeidler 1992; Jennings et al. 1997). Using newly acquired genetic knowledge in a real world context helps students understand the genetic concepts and provides motivation for their learning by answering the eternal question: Why do we have to learn this? Students also benefit from practicing a decision-making process that can be applied in many situations in their lives.

\section{Career Awareness and Preparation}

Genomics provides a wide variety of career opportunities requiring advanced degrees in diverse areas like biological research, health care, computer science, and science writing. In addition, the biotechnology industry and related fields provide entry-level technical positions that do not require college degrees.
Nationally, only $\sim 25 \%$ of high school students go directly to college, so these entry-level positions are an important option to many students (Education Development Center, Inc. 1995). High school biology teachers have a critical role in informing students about both entry level and advanced careers, as well as providing the knowledge and skills to compete successfully for these positions.

\section{The Importance of Partnerships in Facilitating Education in Genomics}

The most effective way for scientists to make a contribution to education in genomics is in collaboration with high school science teachers, either on an individual basis or through an established outreach partnership. By getting involved in pre-college education, scientists have the opportunity to share the excitement of their field of research with teachers and students, collaborate in the development of quality education programs, and learn from outstanding teachers. This involvement benefits the science community directly by helping to produce a more scientifically literate 
population, which, in turn, affects how the public perceives and accepts scientific endeavors. When participating in outreach activities, scientists need to recognize the multifaceted needs and interests of high school teachers and their students, which may be much more general than their own. Furthermore, both teachers and scientists need to respect the knowledge and skills of their counterparts and recognize that there is a great deal they can learn from each other (DeRosa and Krauss 1997). The perspectives of three individuals who have had key roles in the development of the High School Human Genome Program at the University of Washington are presented in Figure 2.

Partnerships often start with individual scientists and teachers working together to affect the learning of a small number of students, and these partnerships are very beneficial for all participants. Ultimately, outreach programs should strive to be sustainable by developing broad-base partnerships that include teachers, school district administrators, scientists, ethicists and members of the business community. Each partner provides a crucial element to the program-scientists and ethicists ensure the authenticity of the information presented; teachers ensure that the materials are taught in a way that meets the needs of the target audience; school district administrators contribute to program sustainability by integrating the program into the science curriculum and providing funds to support it; and business leaders provide human, financial, and material resources. Program sustainability requires long-term commitment by the partner institutions and the ongoing procurement of material resources and financial support.

The following anecdote illustrates how small individual outreach efforts can catalyze widespread change in science education. While one of the authors of this review (M.M.) was a graduate student, her thesis advisor, Bruce Alberts, led a group of $\sim 10$ high school students on a short tour of the laboratory, pointing out features like automatic pipettors, bunsen burners, the water still, and fermentors (much to the amusement of lab members). From this event, and through conversations with teachers and university colleagues that followed over the next 2 years, Alberts spearheaded the development of a partnership program between the
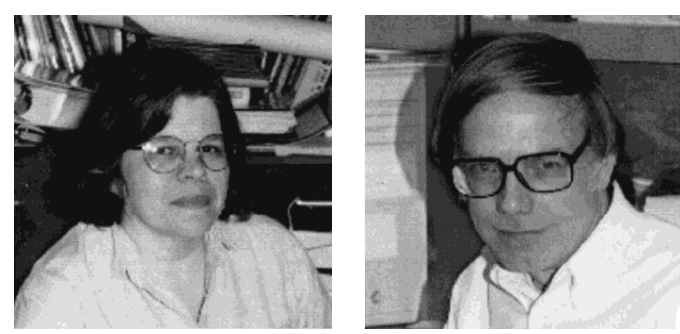

Figure 2 Impact of outreach involvement on different partners. We asked three partners in the encome Program: "How does collaborating in science education outreach and concepts to the examination of important questions, both philosophical and practical, using sonal decisions that are auton leads to an empowering of individuals to make authentic per列 research problems-come from this world, not from within the university. More contact with the community will change the values of the university-for example, increasing the rewards in the and contributions."

University of California San Francisco (UCSF) and the San Francisco Unified School District (SFUSD). The initial approach of this partnership was to link, one-onone, scientists (e.g., graduate students and postdoctoral fellows) with individual K-12 science teachers throughout San Francisco. In 1987, the UCSF Science and Health Education Partnership (SEP) program was formally established as a collaboration between the school district and the university (Clark 1996). Subsequently, the UCSF SEP program participated in form-

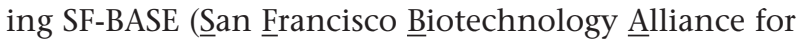
Science Education), a partnership of the SFUSD and San Francisco colleges and universities that promotes and supports biotechnology education in middle and high schools throughout the district. Five other biotechnology education partnerships similar to SF-BASE have been established in the San Francisco Bay area, including the Gene Connection partnership in San Mateo County (Black et al. 1993) and the Santa Clara County Biotechnology Education Partnership, cofounded by one of the authors (G.H.). The Genentech Foundation for Biomedical Sciences has provided substantial start-up and ongoing funding for these partnerships. To support their mutual needs, these six partnerships have established a nonprofit organization called the Bay Area Biotechnology Education Consortium (BABEC).

\section{How Genome Researchers Can Contribute to Science Education}

An efficient way to become involved in educational 
activities is to volunteer with an existing outreach program at a local university, research laboratory, company, museum, or professional society. To identify education programs in your area, please refer to one of the databases describing outreach programs listed in Table 3. Another option is to directly contact a science teacher at a local school who is interested in forming a partnership with a scientist. Box 1 presents a variety of ways that scientists can make a contribution on an individual basis or as part of an outreach program. For detailed instructions about how to get involved in outreach or develop a new scientist-teacher partnership, please refer to NRC (1996b; see Table 2 for URL), Alberts (1993), or the web site of the NRC program, RISE (Resources for Involving $\underline{S}$ cientists in Education; see Table 1 for URL). Potential funding sources are listed in Table 2 .

\section{Institutions and Organizations that Participate in Education in Genomics}

In this section we discuss the many kinds of organizations involved in genomics education. The examples we cite do not constitute a comprehensive list of programs or activities. We are currently in the process of developing a Genetics Education Database and request that interested parties submit a description of their genetics outreach program if it is not already listed (http://genetics-education.mbt.washington.edu/ database). URLs for all of the outreach programs described in this paper are listed in Table 1.

Two- and 4-Year Colleges and Universities, Genome Centers, and Research Institutes

A growing number of university science departments and research institutes include outreach activities as an integral part of their departmental commitments. These programs benefit from the diverse human, material, and financial resources that a university provides and the potential for collaborations with other departments, including colleges of education.

An increasing number of school-to-work programs focus on the preparation of technicians for the biotechnology industry. Characteristically, these programs are developed by partnerships consisting of community colleges, high schools, and industrial part-

\begin{tabular}{|c|c|}
\hline $\begin{array}{l}\text { Database or education } \\
\text { outreach list }\end{array}$ & URL (http://) \\
\hline $\begin{array}{l}\text { Genetics Education } \\
\text { Database }\end{array}$ & $\begin{array}{l}\text { geneticseducation.mbt. } \\
\text { washington.edu/database }\end{array}$ \\
\hline $\begin{array}{l}\text { Guide to Math and } \\
\text { Science Reform }\end{array}$ & $\begin{array}{l}\text { www.learner.org/collections/ } \\
\text { mathsci/ }\end{array}$ \\
\hline NRC (1996b) & www.nap.edu/info/browse/htm \\
\hline
\end{tabular}

ners. A prime example is a California program coordinated by a partnership between Berkeley Biotechnology Education, Inc., a private nonprofit foundation (Berkeley, CA) and Laney Community College (Oakland, CA). These partners coordinate a program involving, at present, two large urban school districts and $>35$ industrial and manufacturing laboratories. This 3-year, laboratory-intensive program targets local, low-income minority students at two high schools in the Berkeley area. Course work spans grades 11 and 12 in the high schools and the first year at Laney Community College. The course curriculum, which emphasizes math and science related to biotechnology, is designed in close collaboration with the program's industrial partners, and students implement their learning during summer internships (high school students) and yearround co-op jobs (community college students) at the partner industrial sites. Thus far, 19 students have graduated from the program, and $100 \%$ of them have found employment at a local biotechnology company. Initially funded by the Bayer Company as part of its commitment to the Berkeley community, the program is currently supported by a variety of private foundations and an NSF-ATE grant to Laney Community College.

\section{National Laboratories}

Each of the DOE-supported National Laboratories involved in the HGP, including Oak Ridge, Lawrence Livermore, Lawrence Berkeley, and Los Alamos, have outreach programs that support science education in their local communities. The NHGRI maintains an Outreach and Education Office that supports a number of activities for K-12 education. These activities include the development of a web site that provides a genetics glossary and media events of the day and a collaboration in the development of a curriculum supplement in genomics aimed at high school students.

\section{Nonprofit Organizations and Foundations}

The following examples reflect the diversity of activities supported by nonprofit organizations and foundations in genome education.

1. The North Carolina Biotechnology Center (NCBC) was created by the North Carolina State assembly in 1981 to stimulate economic development in biotechnology. This organization supports biotechnology-related research, business development, and education. Their K-12 activities include summer workshops for teachers, loans of equipment and videotapes, and a minigrant program. The unique feature of this program is the ongoing state support, which ensures long-term sustainability.

2. The Biological Sciences Curriculum Study (BSCS), a K-12 educational research and development orga- 
Box 1. Ways That Genome Scientists Can Contribute to Science Education

At the beginning of any outreach activity, the scientist should visit the target audience to get to know them, establish their interests and needs, and define ways to collaboratively meet those needs. The activities listed here are often components of outreach programs or can be pursued on an individual basis.

- Lead a discussion on a special topic in a workshop for teachers or a high school classroom.

- Be available to answer questions from teachers, students, or other groups via phone or e-mail.

- Host a teacher for summer research.

- Work with science teachers to integrate components of genome research into their biology and genetics instruction.

- Provide the equipment, supplies, and expertise to do an experiment in a classroom and assist during the classroom experiment.

- Donate surplus functional equipment and supplies to a local school.

- Assist teachers and administrators of local schools or organizations with writing grants.

- Attend a science event with a science teacher partner (such as a meeting of a local, regional, or national scientific organization).

- Invite teachers, students, or other community members to attend research seminars or poster presentations at your institute.

- Develop a section on the web site of your research institute that explains your research activities in lay terms.

- Collaborate in the development of instructional materials in genomics.

nization founded in 1958, has had a leading role in the development of instructional materials in genomics. Well known for their high school biology textbook (BSCS 1996), BSCS recently has focused on the development of teaching modules that address the science, application, ethics, and informatics of the HGP (Cutter et al. 1992, 1996, 1997).

3. The Genentech Foundation for Biomedical Sciences in Northern California funds local science education partnerships serving grade 6 through community college. Several other foundations support biotechnology education projects, including the Monsanto Fund, which has sponsored the development of several biotechnology curricula by the St. Louis Mathematics and Science Education Center (MO).

\section{Museums}

A number of public museums have exhibits that are focused on DNA science and technology, such as the DNA Learning Center at Cold Spring Harbor Laboratory, the Bradbury Science Museum in Los Alamos, and the San Francisco Exploratorium. In 1995, the Exploratorium featured an exhibit that explored genetics and the HGP from a variety of perspectives (Carlson 1997). Many of the exhibits from this program remain active at the Exploratorium, including an Ethical Scenarios Forum, called ETHEX. This forum presents several scenarios based on ethical, legal, and social issues of genetics and the HGP, and enables the museum visitors and remote users to present their opinions on these topics.

\section{Biotechnology Industry}

The biotechnology industry is becoming increasingly more proactive in the education of the general public, in many cases providing funding, scientific support, equipment donations, and other forms of support for classrooms and the community. For example, a Seattlebased company, Immunex, has made a firm commitment to formal education by employing a full-time Science and Education Manager to coordinate a variety of company outreach activities. Other companies that have made a substantial contribution to biotechnology education include Amgen, Monsanto, Genentech, Inc., and the Applied Biosystems Division of Perkin-Elmer.

\section{Health Care Organizations}

Some health care organizations offer professional development programs and written materials for classroom teaching. For example, many of the 10 regional networks for genetic services that serve the United States, Puerto Rico, and the Virgin Islands (affiliated through the Council of Regional Networks for Genetic Services, or CORN) include outreach to K-12 teachers among their organizational goals. One of these groups, the Pacific Northwest Regional Genetics Group, collaborates with the March of Dimes Birth Defects Foundation to present workshops on human genetics for educators as well as health professionals, using a curriculum they have developed called Designer Genes.

\section{Foundations and Support Groups for Genetic Conditions}

Many of the support groups for specific genetic conditions have developed informational brochures or videos to educate physicians, members of affected families, and the general public. A comprehensive list is provided on the web site of the Human Genome Teacher Networking Project (URL in Table 1).

\section{National Scientific Societies}

Many scientific societies, such as The American Society of Cell Biology and the American Society of Human Genetics (ASHG), include a symposium for high school students and teachers as a part of national meetings. At the 1996 annual meeting of the ASHG in San Francisco, its High School Outreach Program hosted $>170$ students and teachers from 30 high schools for a day of activities that included DNA forensics and conducting PCR genotyping. Following this model, the American Society for Gene Therapy included a symposium for 400 high school students as part of its first annual meeting in Seattle in May 1998. 


\section{How Educational Programs Support Genomics Education}

The successful integration of genomics into all high school biology classrooms requires the following key components: (1) professional development for teachers that provides up-to-date information about genome science, ELSI topics, and training in experimental procedures; (2) implementation and support of classroom experimentation; and (3) development of instructional materials for teaching genomics and related ELSI topics.

Comprehensive outreach programs provide all of these components, although they vary in approach and emphasis. In this section we highlight several unique programs that emphasize different aspects of these important components. As in the previous section, the programs discussed here represent a small subset of the many activities currently in place.

\section{Professional Development for Teachers}

All of the programs discussed below provide extensive professional development for teachers and offer different solutions for implementing DNA experimentation in the classroom.

\section{Science Education Partnership}

Typically, most high school science teachers have never participated in scientific research. To provide this opportunity, the Science Education Partnership at the Fred Hutchinson Cancer Research Center (FHCRC) in Seattle offers a $2 \frac{1}{2}$-week summer institute for middle and high school teachers from Washington. This program was designed by a collaboration of high school teachers and scientists, and lead teachers have a major role in the presentation of the summer workshop. Participants in the workshop are partnered with a scientist mentor at the FHCRC, the University of Washington, or a local biotechnology company and carry out a research project with the assistance of their mentor. They also learn a variety of techniques that they can perform with their students during the school year, using supply kits provided by the program.

\section{Partners in Science}

For a more in-depth research experience, teachers sometimes develop long-term collaborations with research faculty at universities or biotechnology companies. The Partners in Science program, funded by the M.J. Murdock Charitable Trust, provides awards to colleges and universities to support collaborative summer research between high school science teachers and a faculty member in several states in the Pacific Northwest. With funding from the HHMI, the National Institutes of Health (NIH) will soon begin a program that enables secondary teachers from the District of Columbia and suburban Maryland and Virginia to spend the summer doing research in an NIH laboratory.
High School Human Genome Program

Some outreach programs emphasize the ability of students to participate in authentic research as a way of engaging them in genome science. The High School Human Genome Program enables high school teachers and their students to sequence a segment of human DNA, in collaboration with scientists at the University of Washington (see Fig. 1B). This program presents a 1-week summer workshop focused on DNA sequencing and the scientific and ethical issues of the HGP. Throughout the school year, local teachers are provided with all of the equipment and reagents necessary to carry out the sequencing process in their classrooms, as well as a team of scientists to help during experiments and provide a link to the research community. Participants from other regions receive technical advice and DNA templates to help them establish sequencing programs in their communities.

\section{DNA Learning Center and CityLab}

A few biotechnology outreach programs are located in teaching laboratories that are used for both teachers and students. The DNA Learning Center is both a teaching laboratory and public museum located at the Cold Spring Harbor Laboratory. The Learning Center staff provide professional development for biology teachers at the teaching laboratory and at other locations throughout the United States. During the school year, classrooms from surrounding school districts go to the Learning Center to participate in DNA experiments, including bacterial transformation, restriction enzyme analysis, and PCR. Similarly, CityLab at Boston University School of Medicine is a biotechnology learning center that serves middle and high school students and teachers in the Boston area. CityLab offers summer workshops for local teachers, who then lead their students through biotechnology experiments at the teaching laboratory with the assistance of CityLab staff. Other programs offered by CityLab include a mobile laboratory, a Biotechnology Club for grade 7-12 students, Science Fair Projects, and Biotechnology Camp.

\section{Human Genome Teacher Networking Project}

The Human Genome Teacher Networking Project, based at the Kansas University Medical Center, updates middle and high school teachers throughout the United States on applications of the HGP over a 2-year period that includes two 1-week summer workshops. Participants interact with genetic counselors, other genetics professionals, and families affected by genetic conditions and learn about genetic screening and testing, public policy issues, careers, genetic resources, classroom curriculum materials (including hands-on experiments), and Internet-based collaborations with genetics professionals. During the academic year, 
teachers network with peers and genetics professionals while disseminating genetics information to students, colleagues, and the public.

\section{Biotechnology on a Shoestring}

Biotechnology on a Shoestring is a NSF-funded program developed by the National Association of Biology Teachers and its industrial partner, Life Technologies, Inc. It provides a curriculum for carrying out experiments in biotechnology using relatively inexpensive materials and supplies, presenting three-day workshops at several locations throughout the year. Participating teachers implement the program units using materials and supplies from their classroom budget. To obtain administrative commitment for participating teachers, their school principals are required to provide $\$ 200$ for the teacher's travel expenses. Participating teachers agree to present one workshop on the course materials within their community and are encouraged to develop partnerships with other teachers in their community and with a local industry.

\section{Implementation and Support of Classroom Experimentation}

Many techniques in genetic research and biotechnology are suitable for classroom use and enable students to carry out scientific inquiry in this field. To successfully incorporate these techniques into the classroom, teachers need both professional development, as just discussed, and access to the necessary equipment and reagents. There are a variety of ways that teachers can obtain the scientific materials they need: (1) borrow the equipment and reagents from a scientist partner at a local research laboratory or biotechnology company; (2) obtain equipment and supplies from an outreach program that provides them as part of its program activities; (3) take their classroom on a field trip to a teaching laboratory designated for high school classrooms, such as the DNA Learning Center or CityLab; and (4) purchase their own equipment and reagents through their school budget or by applying for small grants.

Typically, teachers employ several of these approaches to get the materials they need. When they first begin to incorporate biotechnology into their classrooms they usually borrow materials, but many teachers strive to obtain their own equipment as they integrate more experimentation into their teaching.

\section{Instructional Materials}

A variety of different approaches and media are used to convey recent information about genomics.

\section{Laboratory Manuals/Textbooks}

High school biology texts generally do not cover topics in biotechnology or genomics in much detail, so more specialized textbooks are being developed to meet this need. The first textbook for teaching introductory high school and college-level biotechnology (Micklos and Freyer 1990) is a manual providing a historical perspective of molecular biology and discussing classical genetics, DNA structure, basic molecular biology, and laboratory techniques for the study of DNA. It also presents specific protocols for several techniques used in molecular biology. Another comprehensive guide to biotechnology, aimed at the high school level, was written as a result of the outreach activities of its authors through the NCBC (Kreuzer and Massey 1996). This textbook presents background information on genetics, molecular biology, and biotechnology, describes activities that model biological processes and experimental procedures, provides protocols for hands-on experiences, and discusses societal issues related to biotechnology.

\section{Curriculum Supplements}

As well as comprehensive textbooks, curricular units that focus on specific topics in genomics are also being developed. The BSCS has provided several teaching modules at the high school level to address the science, applications, ethics, and informatics of the HGP (Cutter et al. 1992, 1996, 1997). BSCS is currently developing a unit on complex inheritance, in conjunction with the NHGRI and the Office of Science Education at NIH. The Hastings Center, a nonprofit research and educational institute focused on bioethics, has developed a resource for teaching bioethics in high school classrooms (Jennings et al. 1997). This book presents several case studies in biomedical fields and provides a decision-making framework to help students discuss the related ethical issues. As part of its Science + Literacy for Health project, the AAAS supported the book by Baker (1997; URL for online version given in Table 1), which introduces genetic concepts in the context of specific case studies. Its simple language, interesting scenarios, and clear descriptions of genetics make it a useful resource for middle and high school teaching.

\section{Internet Resources}

As an increasing number of schools become connected to the Internet, this media is becoming steadily more useful for pre-college genetics education. The Internet offers the advantages of immediacy, the ability to carry out large-scale discussions, and opportunities for students and teachers to use the online research tools that are available to research scientists. Access Excellence (AE) is a national education program sponsored by Genentech, Inc., that uses the Internet to connect high school biology teachers with their colleagues, scientists, and current scientific information on a broad range of topics, including genomics. The site includes a Graphics Gallery with reproducible diagrams related to the science of DNA, a time line of the development of biotechnology, interviews with people who have ca- 
reers in the biotechnology industry, an in-depth presentation of bioethics, and many teacher-written, classroom-tested, genomics-related activities. The Natural History of Genes is a web-based program sponsored by the University of Utah Medical School, the Eccles Institute of Human Genetics, and the Utah Museum of Natural History. This program provides a wide array of information and activities for teaching genetics, as well as links to related sites and notices of workshops for high school teachers. The web site of the DNA Learning Center at Cold Spring Harbor has two innovative tutorials that enable students to access databases of either student alleles for an Alu insert or DNA sequences from the mitochondria of different individuals. Students can carry out several analyses using these data. Other useful features on this site include the Animation Library, which has demonstrations of PCR and cycle sequencing, and a news section that highlights current events pertaining to DNA technology.

\section{Lecture Series}

Another way to present up-to-date content and the excitement of scientific research is through a community-directed lecture series. One example is the Distinguished Speaker Series, which is cosponsored by the TIGR Science Education Foundation, the NRC, and the DOE. For the last 3 years, the HHMI has sponsored an annual event called the Holiday Lectures on Science, which is telecast live by satellite throughout the United States and Canada. This lecture series is aimed at the high school level and features discussions of a particular topic in biology each year by two outstanding scientists. This program also provides a guide for teachers, videotapes of the lectures, and a web site that provides additional resources. The value of this program for high school students is in witnessing the level of enthusiasm and commitment of distinguished scientists, gaining perspective about the significance of a body of scientific work, and the validation of the subject matter that the students are learning in the classroom.

\section{Laboratory Tours}

Tours of research facilities provide students with a sense of the "feel" of a laboratory, give them a chance to talk to the diverse collection of individuals who work in research laboratories, and often include opportunities to participate in hands-on experiments. Many research institutes and biotechnology companies, such as the Seattle-based Immunex, provide tours to students, teachers, and other community members on a routine basis.

CD-ROMs, Audio and Video Tapes, and Laser Discs

A variety of products developed commercially or as part of outreach activities are used in classrooms to enhance teaching or provide independent learning.
Teachers frequently use excerpts from quality science programs produced by the Public Broadcasting Station. A recent example is the DOE-funded documentary, "A Question of Genes," which explores the profound challenges confronted by families at risk for genetic disorders as they consider genetic testing. This series is available on video, and a teacher's guide has been developed. The newly released radio series, "The DNA Files," which focuses on the social implications of human genome research, is also available on tape.

\section{CONCLUSIONS}

Genomics education provides many avenues for involving students in the excitement of scientific exploration and exposing them to the potential benefits to society that science can provide. The development of effective genome education activities requires the collaboration of scientists, ethicists, and other genetics professionals, science teachers, school administrators, and the business sector. Whereas the programs and materials referenced here are excellent examples of what can emerge with a collaborative effort, there is still much to do to reach our national goal to make science available for all Americans.

\section{ACKNOWLEDGMENTS}

We thank Cindy Desmarais and Eric Moon for construction of the database; Cindy Desmarais for preparation of the figures; and Ethan Allen, Leroy Hood, and Nancy Hutchison for critical reading of the manuscript. In particular, we thank Bruce Alberts, Leroy Hood, Maynard Olson, and Richard Myers for their long-standing commitment to education outreach.

Funding for the High School Human Genome Program and M.M. is provided by the DOE (grant DE-FG0398ER62547/AM01); funding for the development of the DNA Snapshots curriculum and L.C. was provided by the NHGRI (grant NIHHG00206); and G.H. was supported as Teacher-inResidence by the DOE (grant DE-FG03-96ER62161/AOO2), which we gratefully acknowledge.

\section{REFERENCES}

Alberts, B.M. 1993. 10-step recipe for starting a partnership program. In Science education partnerships (ed. A. Sussman), pp. 15-18. University of California San Francisco, San Francisco, CA.

American Association for the Advancement of Science (AAAS). 1989. Science for all Americans. Oxford University Press, New York, NY.

. 1993. Benchmarks for science literacy. Oxford University Press, New York, NY.

Baker, C. 1997. Your genes, your choices: Exploring the issues raised by genetic research, American Association for the Advancement of Science, Washington, D.C.

Biological Sciences Curriculum Study (BSCS). 1996. Biological science: A molecular approach, 7th edition. D.C. Heath and Company, Lexington, MA.

Black, S., K. Liu, and S. Ogren. 1993. San Mateo County biotechnology-education project. San Francisco State University School of Education Review 5: 125-129.

Brinckerhoff, R.F. and D.L. Zeidler. 1992. One-minute readings: Issues in science, technology, and society. Addison-Wesley Publishing Company, Menlo Park, CA. 
Carlson, C. 1997. Diving into the gene pool. In Here and now, contemporary science and technology in museums and science centers (ed. Graham Farmelo and Janet Carding), pp. 271-278. Science Museum, London, UK.

Clark, M. 1996. A successful university school district partnership to help San Francisco's K-12 students learn about science and medicine. Academic Med. 71: 950-956.

Council of Chief State School Officers. 1995. State indicators of science and mathematics education, pp. 28-30. Washington, D.C.

Cutter, M.A., E. Drexler, L.B. McCullough, J.D. McInerney, L.M. Micikas, R.J. Mural, J.C. Murray, B. Rossiter, and J. Zola. 1992. Mapping and sequencing the human genome: Science, ethics, and public policy. Biological Sciences Curriculum Study, Colorado Springs, CO.

Cutter, M.A., E. Drexler, K.S. Gottesman, P.G. Goulding, L.B. McCullough, J.D. McInerney, L.M. Micikas, R.J. Mural, J.C. Murray, and J. Zola. 1996. The Human Genome Project: Biology, computers, and privacy. Biological Sciences Curriculum Study, Colorado Springs, CO.

Cutter, M.A., E, Drexler, B.E Friedman, L.B. McCullough, J.D. McInerney, J.C. Murray, B. Rossiter, and J. Zola. 1997. The puzzle of inheritance: Genetics and the methods of science. Biological Sciences Curriculum Study, Colorado Springs, CO.

DeRosa, D.A. and R.D. Krauss. 1997. Scientist/educator partnerships provide rich learning opportunities. The Scientist 11: 9; available on-line at http://www.the-scientist.library.upenn.edu/yr1997/ oct/comm_971027.html.
Education Development Center, Inc. 1995. Gateway to the future: Skills standards for the bioscience industry. Education Development Center, Inc., Newton, MA.

Jennings, B., K. Nolan, C. Campbell, S. Donnelly, E. Parens, L. Turner, and E. DeVaro. 1997. New choices, new responsibilities: Ethical issues in the life sciences, 2nd ed. The Hastings Center, Briarcliff Manor, NY.

Kreuzer, H. and A. Massey. 1996. Recombinant DNA and biotechnology. ASM Press, Washington, D.C.

Lynch, E.D., M.K. Lee, J.E. Morrow, P.L. Welcsh, P.E. Leon, and M.-C. King. 1997. Nonsyndromic deafness DFNA1 associated with mutation of a human homologue of the Drosophila gene diaphanous. Science 278: 1315-1318.

McInerney, J.D. 1995. The human genome project and biology education. Bioscience 45: 786-791.

Mertens, T.R. and J.R. Hendrix. 1982. Responsible decision-making: A tool for developing biological literacy. Am. Biol. Teacher 44: $148-152$.

Micklos, D.A. and G.A. Freyer. 1990. DNA science: A first course in recombinant DNA technology. Cold Spring Harbor Laboratory Press, Cold Spring Harbor, NY.

National Research Council (NRC). 1996a. National science education standards. National Academy Press, Washington, D.C.

- 1996b. The role of scientists in the professional development of science teachers. National Academy Press, Washington, D.C.

Received June 4, 1998; accepted in revised form May 7, 1999. 


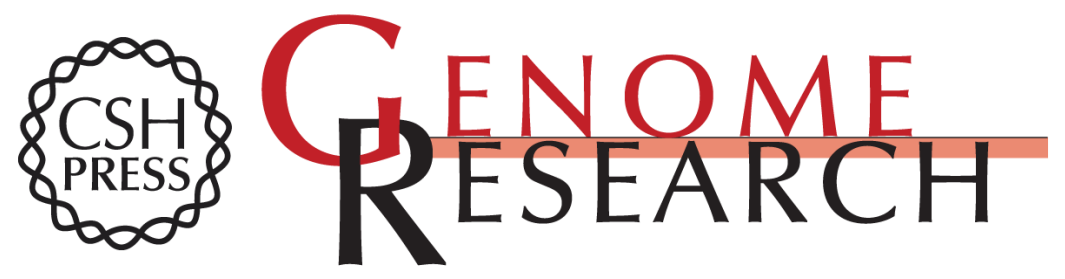

\section{The Involvement of Genome Researchers in High School Science Education}

Maureen Munn, Peggy O'Neill Skinner, Lane Conn, et al.

Genome Res. 1999 9: 597-607

Access the most recent version at doi:10.1101/gr.9.7.597

References This article cites 4 articles, 1 of which can be accessed free at:

http://genome.cshlp.org/content/9/7/597.full.html\#ref-list-1

\section{License}

Email Alerting Receive free email alerts when new articles cite this article - sign up in the box at the Service top right corner of the article or click here.

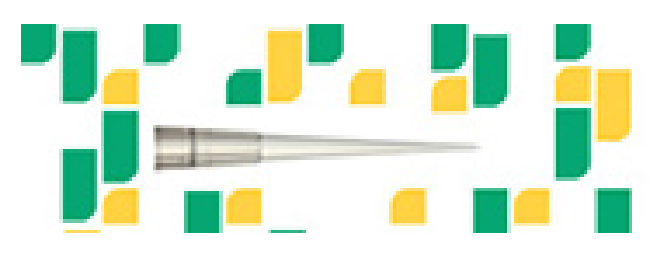

To subscribe to Genome Research go to: https://genome.cshlp.org/subscriptions 